$\mathrm{A} \int_{\text {iss }} \mathrm{H}$

Article history :

Received : 11.07.2018

Revised : 05.11.2018

Accepted : 17.11.2018
Members of the Research Forum

Associated Authors:

${ }^{1}$ Department of Horticulture, Faculty

of Agriculture, Annamalai

University, Annamalainagar,

Chidambaram (T.N.) India
Author for correspondence : E. Arivazhagan

Department of Horticulture, Faculty

of Agriculture, Annamalai

University, Annamalainagar,

Chidambaram (T.N.) India

Email : arivu2@rediffmail.com
THEASIAN JOURNALOF HORTICULTURE

Volume 13 | Issue 2 | December, 2018 | 45-49

Visit us -www.researchjournal.co.in
RESEARCH PAPER

DOI : 10.15740/HAS/TAJH/13.2/45-49

\title{
Influence of plant growth regulators on yield and quality characters of brinjal (Solanum melongena L.) cv. ANNAMALAI
}

\section{E. Arivazhagan, A. Kavitha ${ }^{1}$ and R. Kandasamy ${ }^{1}$}

ABSTRACT : A field experiment was carried out to study the effect of plant growth regulators on growth and yield of brinjal cv. ANNAMALAI. The growth regulators were applied in three different concentrations viz., NAA (25, 50 and $100 \mathrm{ppm}), \mathrm{GA}_{3}(50,100$ and $200 \mathrm{ppm})$ and ethrel $(50,100$ and $200 \mathrm{ppm})$. The experiment was laid out in Randomized Block Design (RBD) with ten treatments and three replications. The earliness in flowering, number of flowers, fruit set percentage, fruit length, fruit girth, fruit weight and yield per plant were registered in the plants sprayed with $\mathrm{GA}_{3} @ 50 \mathrm{ppm}$. The fruits obtained from the plants that were sprayed with GA $@$ $200 \mathrm{ppm}$ also recorded highest total soluble solids and ascorbic acid content, which ultimately had better taste than the other treatments. Among the growth regulators tested, GA $@ 50$ ppm was found to produce best results in improving the growth and yield of brinjal cv. ANNAMALAI.

KEY WORDS : Brinjal, NAA, GA, Yield characters

HOW TO CITE THIS ARTICLE : Arivazhagan, E., Kavitha, A. and Kandasamy, R. (2018). Influence of plant growth regulators on yield and quality characters of brinjal (Solanum melongena L.) cv. ANNAMALAI. Asian J. Hort., 13(2) : 45-49, DOI : 10.15740/HAS/TAJH/13.2/45-49. Copyright@ 2018 : Hind Agri -Horticultural Society 